\title{
Chapter 14 \\ DMDU into Practice: Adaptive Delta \\ Management in The Netherlands
}

\author{
Pieter J. T. M. Bloemen, Floris Hammer, Maarten J. van der Vlist, \\ Pieter Grinwis and Jos van Alphen
}

\begin{abstract}
- Generic rules on how to organize the process of putting DMDU approaches and tools into actual practice are currently lacking.

- Lessons can be drawn from the Adaptive Delta Management (ADM) approach used in the Dutch Delta programme on flood risk management, freshwater availability, and spatial adaptation.

- In the context of putting a DMDU approach into practice, three consecutive phases can be distinguished, with specific aspects that require extra attention: (I) Directly following the political decision to actually start a long-term programme that will deal with the deeply uncertain issue, the programme itself should be designed to keep political involvement "at arm's length". (II) Strategy development requires a narrative that explains how uncertainty is dealt with; that narrative should match the specific societal and political context of the moment. (III) Implementing adaptive strategies requires organizational arrangements for systematically accommodating adjustments, a monitoring system for timely detecting of signals, and a decisionmaking process that links directly to its output.

- On a more general level, it can be concluded that DMDU approaches, such as described in the scientific literature, can profit from feedback-feedback from other researchers and feedback from practitioners. Organizing the latter, an
\end{abstract}

P. J. T. M. Bloemen ( $\varangle) \cdot$ J. van Alphen

Staff Delta Programme Commissioner, Ministry of Infrastructure and Water Management,

The Hague, The Netherlands

e-mail: pieter.bloemen@deltacommissaris.nl

F. Hammer

Independent consultant, specializing in executing technical programmes and projects in complex political environments, The Hague, The Netherlands

M. J. van der Vlist

Rijkswaterstaat, Ministry of Infrastructure and Water Management, The Hague,

The Netherlands

P. Grinwis

Member of the Municipal Council of The Hague and Policy Officer for the ChristenUnie in the Dutch Senate and the House of Representatives, The Hague, The Netherlands

V. A. W. J. Marchau et al. (eds.), Decision Making under Deep Uncertainty, https://doi.org/10.1007/978-3-030-05252-2_14 
instrumental element of "coproduction of knowledge", might be more time consuming, but is likely to be very effective.

\subsection{Organizational Aspects of Putting a DMDU Approach into Practice}

It is implicitly assumed by DMDU scholars that their approaches will be welcomed-that they will be embraced politically and accepted institutionally-suggesting that implementing a DMDU approach is mainly a technical and intellectual challenge. Practice, however, shows that in real-life decisionmaking, organizational aspects play a major role in determining the willingness and ultimate success in applying approaches for dealing with deep uncertainty. This chapter explores how the notion of deep uncertainty influences the organization of processes involved in setting up and running an execution-oriented policy programme.

In a typical execution-oriented policy programme, three consecutive and sometimes partly overlapping phases can be distinguished: (I) the phase prior to the actual start of the programme, in which political commitment is mobilized; (II) the phase of strategy development and decisionmaking, focusing on the analysis of the challenges and on inventorying and selecting options for intervening; and (III) the phase of elaboration and implementation of the strategies, in which monitoring and adjustment of strategies are central. These phases may overlap, and it may be necessary to pass through them more than once before producing a stable output.

This chapter distinguishes, for each of these three phases, one aspect that is typical for that phase (and that requires a different way of organization in the case of deep uncertainty compared with the traditional way):

- In Phase I (prior to the actual start of the programme), the aspect that is singled out is the balance between politicization and de-politicization. In the case of deep uncertainty, there is a high risk of under- and overspending. This heightens the threshold for political commitment to take the lead. Actually, addressing this type of issue often requires a deep breath and consistency over long periods of time (implying politics “at arm's length").

- In Phase II (strategy development and decisionmaking), the aspect that is analyzed concerns the way uncertainties are addressed in strategy development. In a situation of deep uncertainty, the statistics necessary for calculating an optimal solution are not available. Several approaches are available for dealing with deep uncertainty, often developed for specific contexts.

- In Phase III (elaborating, implementing, and adjusting the strategy), the design of a monitoring and evaluation system that permits timely adjustments is essential. Choosing an adaptive strategy implies higher requirements for generating and interpreting data on actual and possible future changes in system ${ }^{1}$ conditions and

\footnotetext{
${ }^{1}$ Different categories of systems can be distinguished (physical, societal, and cyber, among others), and combinations. In the context of ADM, reference is made to physical systems.
} 
system integrity. ${ }^{2}$ The dynamic character of the strategies, and the high stakes involved, require continuous alertness of decision makers.

In Sects. 14.3-14.5, these phases, aspects, and organizational implications are illustrated using the experiences in the Netherlands with respect to climate adaptation. The final section (Sect. 14.6) reflects on the results of the way in which uncertainty has been dealt with so far in "climate proofing" of the Netherlands. Section 14.2 introduces the case study.

\subsection{The Case Study: Adaptive Delta Management}

The Netherlands, with a land surface of $34,000 \mathrm{~km}^{2}$, is situated on the North Sea in the combined delta of the rivers Rhine, Meuse, Scheldt, and Ems. With about 17 million inhabitants and a gross domestic product of about $€ 693$ billion, the Netherlands is the eighteenth largest economy worldwide (International Monetary Fund 2018). The fact that nearly $60 \%$ of the country is flood prone makes flood risk management an existential issue for the Netherlands.

The Delta programme plays a central role in climate proofing the Netherlands. The programme has its legislative foundation in the Delta Act, and has a Delta Fund with a budget of $€ 1$ billion per year. This yearly budget is reserved until 2029-and the lifetime of the Delta Fund is prolonged by another year every year. The programme started in 2010, and presently unites the central government, provinces, municipalities, and waterboards on the improvement of flood risk management, reduction of vulnerability to water scarcity, and spatial adaptation (Delta programme Commissioner 2017; van Alphen 2016).

Involving social organizations and the business community, the public authorities that are united in the Delta programme prepared (in the period 2010-2014) five "Delta Decisions". These over-arching (or key) decisions form the basis of the work that the Netherlands will perform over the next 35 years (with a planning horizon of 2100). The decisions concern new flood safety standards, sustainable freshwater provision, climate-resilient design and construction of urban and rural areas across the Netherlands, and regionally structuring choices for flood risk management and freshwater supply in two critical regions: the IJsselmeer region and the Rhine-Meuse delta. Six regional strategies were developed iteratively, consisting of goals, measures, and a tentative timeline. These regional strategies were developed in the regional subprogrammes of the Delta programme, in which the national government, provinces, municipalities, and waterboards work together, involving the scientific community, NGO's, and the private sector.

\footnotetext{
${ }^{2}$ In line with the terminology used in chapter 13 'system integrity' is defined as "A system's state where its intended functions are being performed without degradation or being impaired by other changes or disruptions to its environments." (From 'The Law Dictionary'). Changes in system integrity may signal degradation in integrity, and may represent a failure mode.
} 
Four "Delta Scenarios" were developed to guide the process of formulating the Delta Decisions and constructing the regional strategies (Bruggeman et al. 2011; Bruggeman and Dammers 2013; KNMI 2014). These scenarios combine the two main sources of uncertainty that determine the future water challenges: climate change and socio-economic conditions.

The existing flood safety standards were based on the size of the population and value of investments in the early 1960s. The new standards, which came into effect on January 1, 2017, take into consideration the "high end" of the four Delta Scenarios. For 2050, the date on which the new protection level has to be realized, they assume considerable climate change (average temperature +2 degrees, sea level rise $+35 \mathrm{~cm}$, and winter precipitation $+14 \%$ ), an increase in population (to 20 million people), and an increase in the value of investments (ongoing economic growth of $2.5 \%$ a year).

The Delta Plan on flood risk management and the Delta Plan on freshwater, both financed from the Delta Fund, comprise the measures from the regional strategies. The Delta Decisions, regional strategies, and two Delta Plans formed the central elements of the proposal sent to Parliament in September 2014. The proposal contains a total of 14 adaptation pathways, developed with a planning horizon of 2100 . The proposal was accepted and the necessary annual budget of over $€ 1$ billion until the end of 2028 was allocated (Delta programme Commissioner 2014).

From discussions in the year the Delta programme was set up (2009), the choice evolved to tailor "our own" approach for dealing with deep uncertainty, an approach that matches the specific characteristics and context of the Dutch Delta programme. Elements from available methods would be "cherry-picked" to build an approach that would fit well with the mission and tasks of the programme, would easily be explainable to policymakers from regional and local public authorities that were to develop the regional strategies, and would offer both structure (for consistency) and flexibility (for tailoring to theme-specific and region-specific characteristics).

The approach was named "Adaptive Delta Management" (ADM). The process of developing ADM was inspired by the practical experience of the UK Thames Estuary 2100 programme (Environment Agency UK 2012) and the development of the DAPP approach by the knowledge institute Deltares (Haasnoot et al., Chap. 4 of this book; Lawrence et al., Chap. 9 of this book). ADM follows an adaptive and integrated approach: adaptive in order to be able to speed up or temporize efforts or to change strategy if the actual or expected rate of climatic and socio-economic developments indicate this might be necessary (Dessai and Van der Sluijs 2007; Van Buuren et al. 2013), and integrated in order to address the highly interconnected fields of water management and physical developments that characterize dynamic and densely populated deltas. The value of combining an adaptive and integrated approach in water management had been shown by in-depth research on water management regimes across Europe, Africa, and Asia (Huntjens et al. 2011). 


\subsection{Phase I: Prior to the Start of ADM (Politicization and De-politicization)}

Addressing a deeply uncertain issue such as climate adaptation in a policy programme often requires a "deep breath" and consistency over long periods of time. These characteristics need to be built into the programme. That programme needs to be built shortly after the "founding decision," in order to make maximum use of the political momentum. This implies a swift change in the character of the central process. Agenda-setting and political debates are often dominated by sweeping statements and firm standpoints; in contrast, setting up a programme requires structure and sobriety. A legislative basis for intervening, and a guaranteed budget, need to be organized. They are necessary conditions for keeping political involvement "at arm's length": well-informed on the main results of the programme, but not incentivized or compelled to actively intervene in every day operational issues. Hence the central question in this phase is: How can the necessary political commitment for starting up a programme of interventions that adequately addresses the issue of a deeply uncertain future be created, and how can stable political commitment in the implementation phase be organized on the main lines of the programme, while keeping more detailed decisions outside the everyday political arena? As stated above, generic rules are lacking, but it can be informative to describe how this was done in the process of climate proofing the Netherlands.

\subsubsection{Build a Constituency for Change that Will Allow Political Commitments to Be Made}

Building a constituency for change that will allow political commitments to be made is not a singular action deliberately planned and executed by an individual organization. It is an evolving process. In the case of the Delta programme, that process was fed by many organizations and events, including formal advice on the subject of climate adaptation by National Planning Bureaus and knowledge institutes (e.g., Netherlands Environment Assessment Agency (MNP) 2005); and The National Institute for Public Health and the Environment (RIVM) 2004; and National Advisory Committees (e.g., The Netherlands Scientific Council for Government Policy (WRR) 2006; Council for Housing, Spatial Planning, and Environment (VROM-raad) 2007). They stimulated the debate on what was to be expected in terms of changing climatic conditions, and what could be adequate interventions.

Political interest for climate adaptation in general was growing, but there was no consensus yet on where to begin and how to approach this issue. Following the March 2005 motion of Senator Lemstra on the necessity of an investment strategy that anticipates long-term developments like climate change and sea level rise, the Ministry of Housing, Spatial Planning, and Environment took the initiative, in May 
2005, to set up the national programme Climate Adaptation and Spatial Planning (ARK).

Creating awareness about the necessity for climate adaptation was one of the major challenges at the start of the ARK programme. On that subject, ARK got a major boost when Hurricane Katrina caused New Orleans to flood in August 2005. Already for a long time there had been discontent with the way flood risk was managed in the Netherlands, and the (near) flooding of the Rhine and Meuse river system in 1993 and 1995 had already resulted in a decision to prepare for unprecedented future peak discharges. The flooding of New Orleans added to the pressure building up that something needed to be done. It was a wake-up call in the sense that, also in a highly developed Western country, disastrous floods are possible. That event, and the movie An Inconvenient Truth, ${ }^{3}$ helped get the adaptation process under way in the Netherlands. Along that line, the Netherlands Environmental Assessment Agency wrote in the foreword of their December 2005 report on the effects of climate change in the Netherlands: "The scientifically indisputable changes in the climate and extreme weather conditions elsewhere raise questions as to the possible effects for the Netherlands" (Milieu- en Natuur Planbureau 2005, p. 3). The arguments used in the Working Plan for the ARK programme (Ministries of Housing, Spatial Planning, and Environment et al. March 2006) for mobilizing political commitment are given in Table 14.1. The columns of the table highlight respectively the priors, the updates, and the new understandings. The rows are more or less in chronological order, often overlapping in time. The organizations that contributed to the new insights range from the IPCC and the Royal Netherlands Meteorological Institute (especially rows 1-3), planning bureaus and advisory councils (especially rows 4-6), knowledge institutes, specialized consultancies, and nongovernmental organizations (especially rows 5-7), and the private sector (especially row 7 ).

The ARK programme, uniting the four levels of government (national, provinces, municipalities, and waterboards) and the relevant knowledge institutes, produced the first Dutch National Adaptation Strategy (NAS) (Ministries of Housing, Spatial Planning, and Environment et al. 2007). The NAS was formally approved by the Government in 2007. In the NAS, flood safety was identified as one of the most pressing of four issues that had to be addressed. ${ }^{4}$ The combination of the attention for climate change from dramatic events abroad, and the processes set up by the ARK programme for drafting the NAS, further increased the public and political attention.

Developing a constituency for change might be a pre-condition for political commitment-but it does not automatically lead to it. The constituency for change was growing, but a substantial political commitment to establishing a major climate adaptation programme apparently required more than that. The grand politically mobilizing perspective was still missing. The initiative for generating that perspective would not come from the Ministry of Housing, Spatial Planning, and Environment, which

\footnotetext{
${ }^{3}$ May 2006; released in the Netherlands October 2006.

${ }^{4}$ The other three were: living conditions (heat stress and cloudbursts), biodiversity (shifts in ecosystems, salinization), and economy (vulnerability of vital infrastructure; transport, energy, communication).
} 
Table 14.1 Why start now with a national adaptation programme (Ministries of Housing, Spatial Planning, and Environment, et al. 2006)

\begin{tabular}{|c|c|c|}
\hline At first we thought ... & But now ... & So ... \\
\hline $\begin{array}{l}\text { 1. We will prevent climate } \\
\text { change by reducing } \\
\text { greenhouse gas emissions } \\
\text { following agreements made in } \\
\text { the UN IPCC context }\end{array}$ & $\begin{array}{l}\ldots \text { we see that the } \\
\text { agreements are not met, that } \\
\text { the measures that are taken } \\
\text { are not sufficient, and that } \\
\text { the climate will continue to } \\
\text { change, at least in the } \\
\text { coming decades }\end{array}$ & $\begin{array}{l}\ldots \text { parallel to the } \\
\text { mitigation-track (reducing } \\
\text { greenhouse gas emissions) } \\
\text { an adaptation track is } \\
\text { needed (reducing the } \\
\text { negative consequences of } \\
\text { the changing climate) }\end{array}$ \\
\hline $\begin{array}{l}\text { 2. Climate change is a gradual } \\
\text { process that might cause } \\
\text { problems in the far future }\end{array}$ & $\begin{array}{l}\text {... we know that climate } \\
\text { change is also about an } \\
\text { increase in the likelihood of } \\
\text { extremes; and that these } \\
\text { extremes might happen } \\
\text { tomorrow }\end{array}$ & $\begin{array}{l}\text {... time for a loud wake-up } \\
\text { call; a broader awareness of } \\
\text { possible consequences is } \\
\text { indispensable }\end{array}$ \\
\hline $\begin{array}{l}\text { 3. We should concentrate on } \\
\text { model calculations of global } \\
\text { weather systems }\end{array}$ & $\begin{array}{l}\ldots \text { we notice that } \\
\text { translations to the local } \\
\text { context require concrete } \\
\text { information at a lower scale }\end{array}$ & $\begin{array}{l}\ldots \text { we need to connect } \\
\text { generic signs with local } \\
\text { experience }\end{array}$ \\
\hline $\begin{array}{l}\text { 4. In the far future we will have } \\
\text { to include climate change in } \\
\text { our investment decisions }\end{array}$ & $\begin{array}{l}\text {... we realize that cost } \\
\text { efficiency of investments } \\
\text { (e.g., in infrastructure, flood } \\
\text { protection, etc.) will already } \\
\text { be influenced by the } \\
\text { climatic conditions in the } \\
\text { coming decades }\end{array}$ & $\begin{array}{l}\text {... the policy instruments } \\
\text { that are used to compare } \\
\text { different investment options } \\
\text { (e.g., benefit-cost analysis) } \\
\text { need to be re-calibrated in } \\
\text { order to better include costs } \\
\text { and benefits in the long term }\end{array}$ \\
\hline $\begin{array}{l}\text { 5. The different national } \\
\text { departments are reasonably in } \\
\text { control of their policy field } \\
\text { and can add a paragraph on } \\
\text { climate adaptation }\end{array}$ & $\begin{array}{l}\text {... the interaction among } \\
\text { the different possible effects } \\
\text { contributes to the urgency } \\
\text { of the problem; a series of } \\
\text { sectoral interventions will } \\
\text { not be sufficient }\end{array}$ & $\begin{array}{l}\ldots \text { we now choose for an } \\
\text { integrated cross-cutting } \\
\text { approach }\end{array}$ \\
\hline $\begin{array}{l}\text { 6. Climate change is an } \\
\text { environmental issue that is } \\
\text { mainly about flood protection, } \\
\text { so certainly the responsibility } \\
\text { of government }\end{array}$ & $\begin{array}{l}\text {... climate change is a broad } \\
\text { societal issue with large } \\
\text { social and economic } \\
\text { consequences for all parties }\end{array}$ & $\begin{array}{l}\text {... climate adaptation } \\
\text { requires close cooperation } \\
\text { among governments, } \\
\text { knowledge institutes, the } \\
\text { private sector, and NGOs }\end{array}$ \\
\hline $\begin{array}{l}\text { 7. Climate change is a problem } \\
\text { now, and will be a big problem } \\
\text { in the future }\end{array}$ & $\begin{array}{l}\ldots \text { climate change also } \\
\text { offers opportunities }\end{array}$ & $\begin{array}{l}\text {... it is important to } \\
\text { explicate, at national, } \\
\text { regional, and local scale, the } \\
\text { opportunities of a changing } \\
\text { climate, both for the private } \\
\text { and public sectors }\end{array}$ \\
\hline
\end{tabular}


had the lead in the climate adaptation dossier with the ARK programme producing the NAS, but from the "competing" Ministry of Transport, Public Works and Water Management.

\subsubsection{Develop Attractive and Plausible Perspectives: The Second Delta Committee}

In June 2007, as the NAS was being discussed in the Cabinet, the Ministry of Transport, Public Works and Water Management published the Water Vision (Ministry of Transport, Public Works and Water Management 2007). The background for this vision was the backlog in maintenance of the dike system, the fact that the flood safety standards were outdated, and the feeling that climate change would sooner or later significantly increase chances of flooding if nothing were done. One of the most important suggestions of the Water Vision was to install an independent, high-level advisory committee on the subject of long-term planning and climate adaptation. The Water Vision was formally approved by the national government on September 7, 2007, and that same day a high-level ad hoc advisory council was installed: the Second Delta Committee.

The Second Delta Committee, combining expertise in water management with expertise in the fields of spatial planning, sustainability, civil engineering, food and agriculture, public finance, communication, and private sector involvement, was asked: "How can we guarantee that our country will remain, for many generations to come, an attractive place to live, work, invest, and recreate?" (Second Delta Committee 2008).

After one year, the Second Delta Committee concluded in its formal advice that the Netherlands would remain an international nexus for goods, services, and knowledge, and that it would not be necessary to displace these to higher grounds. The credo of the Committee's advice was: the situation (the challenges related to flood protection and freshwater supply) is not acute, but it is urgent to begin preparations to deal with them. The Committee concluded that flood protection and freshwater supply in the Netherlands could be guaranteed for the coming centuries, even under worstcase climate change conditions, but the investigations and preparations regarding the necessary measures should start soon (Second Delta Committee 2008). The advice was to build more robustness into the flood safety domain-both in terms of the policy processes that are necessary to speed up investments in flood safety, and in terms of the physical system of rivers, lakes, and sea, and of dunes, dams, and dikes. After delivering its formal advice, the Second Delta Committee was dissolved.

Thanks to the effective cooperation between the Second Delta Committee and the Ministry of Transport, Public Works and Watermanagement, the advice was accepted quickly. Within one week after the advice of the Second Delta Committee was published, the Cabinet published its positive reaction to the advice. Within four months, most of the Committee's recommendations were formally integrated into the 
National Water Plan (Ministry of Transport, Public Works and Water Management, December 2008).

The climate adaptation policy processes were to be stabilized by installing a government commissioner, assigned for periods of seven years, a Delta Fund with a considerable yearly budget, a Delta programme for coordinating measures, and a Delta Act to consolidate this process. The advice also included suggestions for dramatically increasing the robustness of the physical system. Examples: sealing off the Rotterdam area with a ring of floodgates and sluices, constructing new canals, replacing the existing flood protection standards by standards that are 10 times stricter, and raising the water level of the central IJsselmeer Lake by $1.5 \mathrm{~m}$. These were bold measures that would secure protection against floods for centuries. Framing the issue of climate change in this way helped put climate adaptation high on the political agenda. This advice had the "grandeur," the sweeping storylines, and the spectacular interventions that politics had been waiting for.

\subsubsection{Enhance Public Awareness and Political Commitment}

At the peak of public and political attention, generated by the advice of the Second Delta Committee, the "grand decision" was taken to actually start a large-scale climate adaptation programme. Now was the time to organize political commitment on the main lines of the programme, and at the same time build into the programme that politics are kept "at arm's length" in the details of running that programme.

A preparatory team consisting of civil servants from four Ministries ${ }^{5}$ involved in climate adaptation was assigned the task to set up, in 2009, the Delta programme. In the context of programmeming concrete measures, there is more need for nuance than in the context of agenda-setting. Also, to distinguish the role of the Second Delta Committee (the ad hoc advisory council which existed for only the one year that was necessary to formulate the advice) from the role of the Delta programme Commissioner (a permanent high position laid down in the Delta Act), it was decided that the tone of voice of the Delta programme should not be one of looming disasters, but one of sobriety. That switch led to shifting from the "worst-case" futures used by the Second Delta Committee, to the "plausible" Delta Scenarios of the Delta programme Commissioner, covering a wide range of future uncertainty.

The 2014 OECD Study Water Governance in the Netherlands-fit for the future? concludes that the success of the Delta Works following the 1953 flooding came at the price of "a striking 'awareness gap' among Dutch citizens related to key water management functions, how they are performed, and by whom. Similarly, the perception of water risks is low." But the trust of the Dutch citizen in the capacities of the government to manage flood risks is high. And there is no real political debate about the relevance for the Netherlands of a reliable defense system against flooding.

\footnotetext{
${ }^{5}$ The Ministries of Housing Spatial Planning, and Environment; Economic Affairs; Agriculture Nature and Fishery; and Transport, Public Works and Water Management.
} 


\subsubsection{Stabilize Processes; Build Trust and Continuity into the Structure of the programme}

An important ingredient of the advice of the Second Delta Committee is to install a Delta Fund especially assigned for flood risk management and freshwater availability "at distance from the regular national budgets and other funds that have a wider field of application. (...) Funds are available on the moment that they are needed; expenditure follows the realization of the necessary measures. This secures the financial resources necessary for flood risk management and freshwater availability, and prevents competition with the short-term agenda."

As observed in the formal evaluation of the Delta programme in 2016 (Office for the Senior Civil Service (ABD) 2016), the Delta programme Commissioner "operates separately from 'the issues of the day', contributes to depoliticization and continuity ...". It is concluded that "The Delta Act has led to remarkable results in a period of economic setbacks and (in its first period) political instability. The de-politicization-meaning the decoupling of the heat of the day from long-term perspectives - of the water policy domain has contributed to stability in the Parliament around the Delta programme." The Delta Act guarantees "calm on the shortterm (depoliticization, continuity), and (financial) security on both the short- and long-term, all conditional for a successful system as a whole."

The introduction of the new position of the government commissioner for the Delta programme (hereafter called the Delta programme Commissioner) did not provoke much political debate, and there was little media coverage. On a more generic level, introducing a government commissioner implies political recognition of the theme: a relatively free role at a certain distance from ministerial responsibilities and political interference (van Twist et al. 2013, p. 5).

In the decades preceding the disastrous 1953 flood, the risk of dikes breaching during storms was well known, but political and administrative processes consistently prioritized other themes. Deciding to install a Delta programme Commissioner with an influential role at a certain distance from politics resembles the decision of Odysseus ordering his men to bind him to the mast of the ship, and his men to plug their ears, so that the ship could safely pass the Sirens; he wanted his men not to follow his commands in that dangerous part $^{6}$ of the journey. ${ }^{7}$

\subsection{Phase II: Developing Strategies and Decisionmaking}

In a situation of deep uncertainty, there are no statistics available for calculating an optimal solution. As the previous chapters of the book show, there are several

\footnotetext{
${ }^{6}$ Pushing for serious action in calm times defies the immediate demands of political actors. In the case of anticipatory climate adaptation, the narrative of tying to the mast flips from times of turmoil to "calm times".

${ }^{7}$ In political science this is a well known strategy of credibly committing by "tying one's hands".
} 
approaches available for dealing with deep uncertainty. It is difficult to determine up front which approach fits best with your specific issue. But: "Rather than arguing over whether to apply the approach Robust Decision Making or the Dynamic Adaptive Policy Pathways, the discussion should be which combination of deep uncertainty tools are appropriate to use given the nature of the problem situation" (Chap. 15).

\subsubsection{Create a Narrative that Mobilizes Administrative and Political Decisionmakers}

It was clear for all parties involved that the notion of uncertainty should have an explicit place in the process of developing strategies. By choosing for an adaptive approach, the Delta programme Commissioner gave a clear signal that resonated with both the believers and the deniers of man-induced climate change: in developing adaptive strategies and proposing costly measures he would not only pay attention to the risk of under investing, but also to the risk of overinvesting. Inherent to this approach for dealing with uncertainty is that adaptivity is key, and (therefore) monitoring is essential.

It also made clear that the new Delta Plans would not automatically contain the same type of gigantic structures as the Delta Plans that was drafted after the flooding of 1953. The near-floods of 1993 and 1995 already changed the flood risk management scene in the Netherlands. Climate change, uncertainty, and the adaptive approach had made their entrance (Zevenbergen et al. 2015). In the wake of Hurricane Katrina a new type of challenge arose. This time it was not about channeling political and societal commitment, mobilized by a flood or near-flood in the Netherlands. In situations in which floods or near-floods form the starting point, these conditions typically "outline" the dimensions of the type of situation that will have to be addressed. In the case of the Delta programme, these "outlining" events had not occurred; now it was about dealing with deep uncertainty about preparing for multiple future developments for which, at the outset, no reliable statistical data are available $^{8}$ and that might become disastrous.

This new situation called for a broader set of interventions, and at the same time allowed more time for designing integrated measures. There was more time and opportunity for tailoring solutions to local challenges and preferences, for combining traditional flood risk management interventions like dike reinforcement with measures providing room for the river, and for spatial measures increasing the flood resilience of built-up areas and for developing and testing emergency plans. In other words: there was time, but also a need for an integrated and innovative approach that would combine the challenge of dealing with uncertainty in future developments

\footnotetext{
${ }^{8}$ Depending on the characteristics of the challenge, appropriate monitoring may be a means to effectively collect data, and transform the data into an increased understanding of the system, thus contributing to a reduction of the uncertainty. Monitoring is critical to the narrative of adaptive strategies.
} 
with the ambition to match solutions with ambitions in other policy fields. As shown by Funfgeld et al. (2018) "organizations working effectively with decision-support tools to adapt to climate change will need to feel ownership of them and have confidence in modifying them to suit their particular adaptation needs and organizational goals."

The narrative of Adaptive Delta Management is best summarized by its four elements (Delta programme Commissioner 2013):

- Connect short-term decisions in the wide field of spatial planning (housing, nature, infrastructure, recreation, etc.) with long-term objectives in the (more narrow) field of flood risk management, freshwater availability, and spatial planning. A typical instance is the construction of a river bypass close to the city of Nijmegen. The bypass is expected to be necessary to accommodate an expected increase in peak river discharges in the coming decades. Although not necessary for dealing with the present-day climatic conditions, it is constructed now to be sure that future urban developments will not sprawl over the allocated area.

- Develop adaptation pathways that visualize what measures address what physical conditions, and estimate when these conditions could occur under what scenario.

- In choosing strategies, look for and "rate" flexibility. The high uncertainty on the possible increase in sea level rise makes sand suppletion an attractive alternative for heightening sea dikes.

- Link Delta programme measures with other investment agendas (e.g., aging infrastructure, urban development, nature, shipping, and recreation). A typical example would be the Prins Hendrik dike in Texel. The flood safety-oriented works foreseen for the dike were adjusted to accommodate ambitions in nature conservation. The additional costs were covered by the regional, nature-oriented Wadden Fund.

\subsubsection{Involve All Parties in Developing an Approach for Dealing with Deep Uncertainty}

The working process for developing the envisioned approach was designed to (a) involve experts from both research institutes and responsible departments in order to arrive at (b) a state-of-the-art approach that (c) can be applied relatively easy in practice and (d) can count on commitment at the level of policymakers. The working process that was constructed in the Delta programme consisted of an organizational complex with the following three categories of organizations contributing.

\section{Coregroup for ADM, Strategy Working Group, and Research Coordinator}

A Coregroup for ADM was assigned the task of developing an approach for dealing with uncertainty that would meet the design criteria (a) through (d), described above. This group consisted of three members of the Delta programme Commissioner's staff and one principal expert from the division 'Rijkswaterstaat' of the Ministry of Infrastructure and Water Management, Rijkswaterstaat division. (These are the first four 
authors of this chapter.) The Coregroup coordinated all activities related to developing the ADM approach and applying it in practice. For the latter, the Strategy Working Group was added to the existing organizational complex of the Delta programme. This group consisted of the senior policy advisors of the subprogrammes of the Delta programme. Depending on the need for support in strategy development, the frequency of meetings varied from once per week to once per month. It was soon concluded that additional support was needed in the form of focused research and model development. The responsibility for that task was assigned to the Research Coordinator of the Committee's Staff (the fifth co-author of this chapter).

\section{Ministerial Working Group for Adaptive Delta Management}

A Ministerial Working Group for ADM was established in which different sections of the Ministries of Infrastructure and Environment, Economic Affairs, Agriculture Nature and Food Quality, and Finance participated. The task of this group was to scrutinize (with a specific focus on juridical, administrative, and financial aspects) the principles underlying ADM, and to discuss possible consequences-both positive and negative - of applying ADM. This process can be viewed as an ex-ante evaluation. The group consisted of eight senior experts with in-depth knowledge of the policy processes in their departments, and of the corresponding requirements for the substantiation of policy options. The discussions contributed to the rigor of the ADM approach, and to support from other departments for applying it in preparing decisionmaking. The group's conclusions were made public in the Delta programme 2012 (Delta programme Commissioner 2011). They concluded that the approach can contribute to reducing chances of over- and underinvesting. They also signaled the risk that keeping long-term options open might result in lost income. No legislative barriers that hinder mutual fine-tuning of measures and ambitions in other policy fields were found. Last but not least, the Ministerial Working Group urged that attention should be paid that further development of the approach should not make it more complex.

\section{ADM Research Network and Specialized Consultancies}

The ADM Research Network was closely linked to the Coregroup. The Dutch knowledge institutes with expertise relevant to the development and application of this approach (Deltares, Delft University of Technology, Wageningen University Research, Royal Netherlands Meteorological Institute, Netherlands Environmental Assessment Agency) were represented in this group. The Research Network made specialized contributions to the process and reflected on intermediate results. In addition, specialized consultancies (including Stratelligence, Blueconomy, and Royal Haskoning DHV-SMC) were actively involved both in developing the ADM approach and in assisting the regional and thematic subprogrammes of the Delta programme in applying it.

ADM was described (in its ideal form) in an extensive manual (van Rhee 2012). But all involved were aware that applying the approach to themes and regions as diverse as in the Delta programme would not be a straightforward matter of following a cookbook recipe. It was decided to actively support the tailoring (and sometimes 
simplification) of the approach to match characteristics of the subprogrammes, such as region-specific interests and data availability. Such further elaboration was performed "on-site" in concert with the national and regional teams responsible for developing the strategies, supported by a team of external experts from knowledge institutes and specialized consultancies.

In terms of organizational interfaces, the Coregroup for Adaptive Delta Management was the central entity. In that group, the findings and questions of the Ministerial Working Group for Adaptive Delta Management, the ADM Research Network, and the Strategy Working Group were discussed and used in the process of developing the ADM manual.

Results from, and experiences in developing and applying, ADM were presented and discussed in national and international conferences with both scientists and practitioners in, among others, the National Delta Conference in 2011 (Amsterdam), the Knowledge Conferences of the Dutch Delta programme in 2012 (Delft), 2013 (Wageningen), and 2014 (Almere), the European Conference on Climate Adaptation in 2013 (Hamburg) and 2015 (Copenhagen), the international conference Deltas in Times of Climate Change in 2014 (Rotterdam), and the annual workshops of the Society for Decision Making under Deep Uncertainty (DMDU) in 2014 (Santa Monica) and 2015 (Delft).

\subsubsection{Evaluate and Upgrade the Approach Regularly}

It is recommended to organize regular evaluations, looking at the approach from different angles, because they contribute to the quality of and commitment to the newly developed approach.

A large-scale survey (645 respondents) done in 2013 by the Erasmus University in Rotterdam (van Buuren and Teisman 2014) on the functioning of the Delta programme showed that $72 \%$ of all respondents agreed that the Delta programme was successful in connecting short-term decisions with long-term objectives-one of the four elements of Adaptive Delta Management. The survey indicated that Adaptive Delta Management and thinking in adaptation pathways are seen as important outcomes of the Delta programme. It was concluded that the three "core qualities" of the Delta programme that need to be preserved in the next phase are "shared ownership," "coherence," and "adaptivity.",

A more focused online survey was performed to gain insight into the experience in the Delta programme of applying in practice the specific aspect of ADM of adaptation pathways (Rijke 2014). The survey addressed the people that actually worked on the formulation of the Delta Decisions and regional strategies-typically policymakers from different levels of government, consultants, and practice-oriented researchers. They assigned the highest added value of applying adaptation pathways to the way

\footnotetext{
${ }^{9}$ In terms of the conceptual elements of Planned Adaptation, described in more detail in Chap. 13, the first two are elements of 'organizational interfaces and engagement'; the last is the 'outcome'.
} 
it helps to incorporate long-term objectives (in flood safety, freshwater supply) into short-term decisions (in a broad range of sectors, including water management, urban planning, nature, aging infrastructure, recreation, and shipping). The added value on this aspect was rated 4.6 out of a maximum of 5 points. The most difficult aspects of DAPP to apply in ADM were the determination of Adaptation Tipping Points (ATPs) and the quantification of the added value of flexibility.

The formal statutory evaluation of the Delta programme, executed in 2016, stressed the importance of maintaining adaptivity in the Delta programme, but stated that it is too early to judge its added value in the phase of elaboration and implementation. Maintaining adaptivity was considered as crucial. At the same time, it ranked high in the top five of major challenges for the future. The evaluation commission urged all parties involved in the Delta programme to acknowledge the importance of maintaining this specific aspect for the successful functioning of the Delta programme.

\subsubsection{Operationalize the DMDU Approach}

Practical experience with applying the adaptation pathway approach in the UK (UK Thames Estuary E2100 project) and the Netherlands (Delta programme) was compared with literature studies in order to formulate challenges for its further development (Bloemen et al. 2017). Two of the most prominent challenges are briefly described below. The overall results of this study are summarized in Table 14.2.

Determining tipping points, in the absence of precise policy goals, for intrinsically flexible strategies, and in situations with large natural variability

An implicit assumption in the adaptation pathways approach (APA) is that some physical parameter, whether it is climatic conditions influencing probabilities of a flood, or socio-economic developments influencing possible consequences of a flooding, changes gradually - thus, slowly but surely forcing society to react, and ultimately switch to a different strategy. This approach seems to work best in the case of gradual trend-dominated developments like sea level rise, forcing a clear-cut decision on, for instance, the upgrading or replacement of a flood surge barrier.

Determining ATPs proved challenging in other contexts. Attempts to operationalize the adaptation pathways developed for freshwater availability in terms of defining when the next generation of measures should be implemented have temporarily been put on hold, as it has become clear that the policy objectives in that field were not precise enough to determine an approximate timing of the tipping points under the different climatological and socio-economic scenarios (Haasnoot et al. 2017).

The strategy chosen in the Delta programme for the threat of flooding from the sea is "beach nourishment." In this strategy, sand is supplied in the sea close to the coast, thus reducing wave erosion. This strategy is intrinsically flexible: every year the volume of sand supplied can be increased or decreased depending on the rate of 
Table 14.2 Lessons learned on the application of the adaptation pathways approach

\begin{tabular}{l|l|l}
\hline $\begin{array}{l}\text { Lessons learned from the application } \\
\text { of the adaptation pathways approach } \\
\text { (APA) }\end{array}$ & Source & Phase \\
\hline
\end{tabular}

Added value of applying APA

\begin{tabular}{|c|c|c|}
\hline $\begin{array}{l}\text { APA is effective in informing and } \\
\text { mobilizing decisionmakers, and in } \\
\text { keeping decision processes going } \\
\text { forward; it helps to gain approval and } \\
\text { buy-into the plan with key stakeholders }\end{array}$ & $\begin{array}{l}\text { Analysis experience UK, NL } \\
\text { Literature review }\end{array}$ & Design \\
\hline $\begin{array}{l}\text { Added value is highest if pathways are } \\
\text { focused at a strategic level of } \\
\text { decisionmaking, e.g., regarding a } \\
\text { concrete investment decision on } \\
\text { water-related infrastructure. It } \\
\text { provides political support for keeping } \\
\text { long-term options open, and motivates } \\
\text { decisionmakers to modify their plans } \\
\text { to better accommodate future } \\
\text { conditions }\end{array}$ & $\begin{array}{l}\text { Analysis experience UK, NL } \\
\text { Literature review }\end{array}$ & Design \\
\hline $\begin{array}{l}\text { APA helps to increase awareness about } \\
\text { uncertainties. It helps to incorporate } \\
\text { long-term objectives into short-term } \\
\text { decisions, offers visualization of } \\
\text { multiple alternatives, and helps } \\
\text { positioning measures in a physical } \\
\text { context and in an indicative timeframe }\end{array}$ & Analysis experience UK, NL & Design \\
\hline
\end{tabular}

Recommendations for organizing the design of adaptation pathways in practice

\begin{tabular}{|c|c|c|}
\hline $\begin{array}{l}\text { Foster "free thinking space" for the } \\
\text { consideration of actions that may not } \\
\text { be politically or financially acceptable } \\
\text { in the short term }\end{array}$ & Analysis experience UK, NL & Design \\
\hline $\begin{array}{l}\text { A test version of adaptation pathway } \\
\text { diagrams early in the development } \\
\text { process is beneficial for } \\
\text { communicating concepts and } \\
\text { garnering stakeholder support }\end{array}$ & Analysis experience UK, NL & Design \\
\hline $\begin{array}{l}\text { Incorporate local information in the } \\
\text { design of the adaptation pathways. } \\
\text { Organize stakeholder participation in } \\
\text { pathway development }\end{array}$ & $\begin{array}{l}\text { Literature review; in line with } \\
\text { experience UK, NL }\end{array}$ & Design \\
\hline
\end{tabular}


Table 14.2 (continued)

\begin{tabular}{|c|c|c|}
\hline $\begin{array}{l}\text { Lessons learned from the application } \\
\text { of the adaptation pathways approach } \\
\text { (APA) }\end{array}$ & Source & Phase \\
\hline $\begin{array}{l}\text { Organize coordination at a higher level } \\
\text { to ensure consistency }\end{array}$ & $\begin{array}{l}\text { Literature review; in line with } \\
\text { experience UK, NL }\end{array}$ & Design \\
\hline $\begin{array}{l}\text { Make periodic updates of the } \\
\text { adaptation pathways }\end{array}$ & $\begin{array}{l}\text { Literature review; in line with } \\
\text { experience UK, NL }\end{array}$ & Design, Implementation \\
\hline \multicolumn{3}{|c|}{ Challenges for the further development of $A P A$} \\
\hline $\begin{array}{l}\text { Determining tipping points in the } \\
\text { absence of precise policy goals, for } \\
\text { intrinsically flexible strategies, and } \\
\text { in situations of large natural variability }\end{array}$ & Analysis experience UK, NL & Design, Implementation \\
\hline $\begin{array}{l}\text { Unraveling the relations among } \\
\text { parallel strategies implemented } \\
\text { simultaneously }\end{array}$ & Analysis experience UK, NL & Design \\
\hline $\begin{array}{l}\text { Maximizing broad commitment } \\
\text { in situations of low predictability }\end{array}$ & Analysis experience UK, NL & Implementation \\
\hline $\begin{array}{l}\text { Preparing a switch to transformational } \\
\text { strategies }\end{array}$ & $\begin{array}{l}\text { Analysis experience UK, NL } \\
\text { Literature review }\end{array}$ & Design, Implementation \\
\hline
\end{tabular}

observed sea level rise. In this case, it is not possible (and not necessary) to determine tipping points-as long as there is enough sand available, there are no tipping points.

The monitoring of the changes in the frequency of storms, droughts, and heat waves remains difficult, due to the lack of observations of extreme events, which are by definition rare. In the case of climate change induced changes in peaks of river discharge, research combining monitoring data with model calculations shows that the natural variability in river discharge is so high that, even when rapid (but not extreme) climate change is assumed, it can take 3-4 decades before the climate change signal can actually be distilled in a statistically sound way from monitoring data on river discharges (Diermanse et al. 2010; Klijn et al. 2012).

From a practical point of view, research is needed to find alternative approaches and/or parameters for distilling the climate change signals from river discharge measurements. This could be achieved through combining data-based detection of changes in observed events with exploration of possible future events through scenarios and modeling (Hall et al. 2014). Accordingly, Haasnoot et al. (2015) identified a possible signaling role for "decreasing summer river discharge" as an indicator for changes in peak river discharge in the River Rhine. 


\section{Preparing the switch from incremental to transformational strategies}

While in theory the pathways approach is "neutral" to the choice of the type and order of measures, practice shows that the selected pathway or the preferred strategy often contains incremental measures in the short term, firmer measures in the middle term, and (options for) system-changing interventions or transformational measures in the long term. The rationale behind this seems obvious: the longer the time horizon, the larger the climatic challenges, thus the heavier the required interventions.

Incremental measures are "protective," in the sense that they can be considered as investments in a further gradual improvement of the resilience of the present system. The flipside is that this may increase the transfer costs to a new or significantly modified system. Increasing the resilience of the present system may also lead to an increase in sunk costs, further increasing the threshold for switching from an incremental strategy to a transformational strategy. It is often stated that there are many plans for transformational measures; but these measures are implemented only as a reaction to extreme events. It is tempting "in calm times" to postpone highly demanding decisions that have their justification only in long-term, uncertain challenges. Comparable to England's TE 2100 Plan, the Delta programme aims "to stay ahead of major flooding." Due to climate change, transformational measures are inevitable in the long term. So at some point in time, the transition from incremental strategies to transformational strategies will have to be made. Though several authors have addressed the difficulty of making a planned shift to transformational strategies (Folke et al. 2010; de Haan et al. 2014; Lonsdale et al. 2015; Rijke et al. 2013), the issue has not yet been tackled adequately.

From this analysis, it also follows that middle-term investments in the resilience of the present system should be re-evaluated in the light of a possible future transition to a significantly modified system. Two options are to adopt shorter depreciation periods, or to consider alternative measures that are specifically designed for relatively short periods.

\subsection{Phase III: Elaborating, Implementing, and Adjusting Strategies}

\subsubsection{Plan the Adaptation}

Choosing an adaptive approach implies being able and ready to adjust frameworks, strategies, and plans. These adjustments themselves need to be prepared. Planned Adaptation, as defined by McCray et al. (2010), hints at the bureaucratic apparatus necessary "to plan for adaptation," but does not explicitly address it. programmes that apply Planned Adaptation "both revise rules when relevant new knowledge appears, and take steps to produce such improved knowledge." This notion is described in detail in Chap. 13. The next subsection elaborates on the experience of applying this notion in the Delta programme. 
Choosing an adaptive strategy imposes higher requirements for generating and interpreting data on actual changes and possible future changes in external physical conditions (e.g., changes in climate, socio-economic conditions, and land use), in knowledge and innovation (e.g., dike stability, modeling techniques, and technology), and societal preferences (e.g., resistance against ever-heightening dikes, willingness to pay for landscape quality, and market value of waterfront housing).

The dynamic character of adaptive strategies, and the high stakes usually involved (e.g., flooding, shortages of freshwater), require the continuous alertness of decisionmakers. The information generated by monitoring and evaluation has to be analyzed, interpreted, and translated into options for adjusting strategies, and ultimately intervening in the implementation of the strategies. Decisionmaking has to be linked directly to the output of the monitoring and evaluation system.

\subsubsection{Organize the Adaptation}

As described in Chap. 13, the organizational complex needs to be prepared to execute adaptive policy recommendations. The object of Planned Adaptation is the character and context of the programmes acting on new knowledge.

The Delta programme combines elements of Dynamic Adaptive Policy Pathways (Chaps. 4 and 9) with elements of Planned Adaptation (Petersen and Bloemen 2015; Chap. 13). This subsection analyzes how three generalizing elements of Planned Adaptation have been incorporated into the Delta programme: the notion of primary and secondary rules, the role of triggers and events, and the organizational characteristics of evaluation. The box below illustrates that adapting a plan is not necessarily a case of Planned Adaptation.

\section{Unforeseen, ad hoc and reactive adaptation of the plan versus planned, systematic, and proactive adaptation.}

Some of the projects that were part of the first Delta Plan (Delta committee 1960) that was established after the 1953 flooding, such as the Oosterschelde storm surge barrier, were not built as originally designed. The Oosterschelde storm surge barrier was adjusted following changes in societal preferences in the early 1970s. These adjustments were not foreseen. The original design was a complete closure of the Oosterschelde from the North Sea by a dam. The first $5 \mathrm{~km}$ of the barrier were built like that. Environmental and local economic considerations led to adjustments in that plan. The remaining $4 \mathrm{~km}$ were built with tidal gates that are open, but can be closed when sea levels rise above certain standards. In an interview in the magazine De Ingenieur (October 4, 2016) Frank Spaargaren, the head of the responsible Rijkswaterstaat section 
at the time, stressed that the engineers that had worked on the original design felt that deviating from it was "a defeat." The adaptation was not planned.

The adaptive approach, in contrast, assumes beforehand that new insights will lead to adjustments, and prepares for accommodating these adjustments; adaptation is not $a d$ hoc and reactive, but is systematic and proactive.

\section{Primary and secondary rules}

McCray's notion of Planned Adaptation is fundamentally about updating rulemaking systems. Adaptation in conventional rulemaking systems, in particular legal systems, can be framed in terms of Hart's primary and secondary rules (1994). Historically, adaptations in legal systems have been ponderous-they are "low clockspeed" precisely because they are reflective of changes in societal norms. In contrast, technical systems move at a faster pace, often at a pace orders of magnitude faster than legal processes. "Primary rules describe what behaviors are appropriate and what behaviors are prohibited. In contrast, secondary rules are about how to recognize, create, maintain, and adjudicate primary rules. Adaptive processes must strike a balance between the canonical objective of regulations (creating stability) and the potential for chaos if feedback loops trigger changes too frequently" (Chap. 13). The challenge is to facilitate rulemaking capability and capacity that satisfies the obligation to system integrity while not falling into the trap of creating chaotic processes by attempting to adapt too frequently.

The Delta programme covers the policy fields of flood risk management, freshwater availability, and spatial adaptation. The field of flood risk management is dominated by substantive "primary rules" in the first of the three levels of the multi-level safety approach: the prevention level. The first level is characterized by quantitative standards for flood protection; the second and third level focus on impact reduction by flood proofing land use (level 2), and adequate disaster management to reduce fatalities (level 3). Policy development in these last two levels has not (yet) resulted in quantitative legislative standards. This also goes for the policy fields of freshwater availability and spatial adaptation.

Among recent acts that are considered important in the field of water management are the Delta Act (2012), the Water Act (2009), and the Flood Protection Act (also called the Water Defence Act (1995)). These acts set fixed time periods for reviewing the safety standards, but do not provide criteria for the adjustments themselves.

Rules, be they primary or secondary, are not necessarily of a legislative nature. The notion of agreeing up front on the criteria that should be applied for adjustments has been incorporated into the Delta programme in the form of rules for "sieving" from the observed and calculated external developments the ones that call for reconsidering of the Delta Decisions or regional strategies. Developments that have actually been measured, and for which a logical physical explanation is available and that are expected to have an impact in the near-future, are considered convincing enough; taken together they inform a set of secondary rules for reviewing the Delta Decisions 
(which comprise primary rules like flood safety standards). Detecting these developments, and using a set of secondary rules to monitor and evaluate, is the task of the Delta programme Signal Group, described in more detail in Sect. 14.5.3.

\section{Triggers and events}

Planned Adaptation defines a trigger as a signal that "potentially affects obligations to integrity" of the system (Chap. 13). In Chap. 13, Sowell distinguishes three types of triggers: periodic triggers and tacit triggers (both proactive in nature), and stochastic triggers (reactive in nature):

- Periodic triggers are clock-driven. Built into the Delta programme are two clockdriven triggers. The over-arching Delta Decisions and regional strategies are systematically reviewed every six years, and the flood protection standards are reviewed every 12 years.

- In the case of tacit triggers, the evaluation of the rules is the starting point, which may result in an adaptation of the policy. In this case, tacit triggers are not monitored by the bureaucracy, but by the constituency itself. ${ }^{10}$ With tacit triggers, the evaluation of events, not the events themselves, activate the process for changing policy. Actors bound by the rules have the option to propose changes at any time; the option to change policies is always available. Characteristic of ADM is that strategies can be adjusted yearly. Different types of evaluation contribute to that process, as described in the next subsection.

- Stochastic triggers are "the direct product of active, continuous monitoring of a system for events that may impact the integrity of the system," (Chap. 13). Stochastic triggers are reactive.

\section{Organizational characteristics of evaluation}

As mentioned earlier in this chapter, monitoring and evaluation play a crucial role in the implementation phase of an adaptive strategy. Three organizational aspects are considered relevant in the context of Planned Adaptation: the timing of evaluation, the composition of the evaluating body, and the degree of coupling between the evaluating body and the actors adversely affected by the rules (Chap. 13).

When it comes to the timing of evaluation, Planned Adaptation distinguishes "ideal types" of assessment capabilities at the two ends of a spectrum of evaluation classes: "active' and "vested" assessment capabilities. Active assessment capabilities monitor continuously; vested assessment capabilities respond to unanticipated events. ADM typically focuses monitoring efforts on the timely detection of changes in developments that are known to be in progress, making it a canonical instance of active assessment. In addition, extreme events are analyzed to improve understanding of the way the water system reacts to changes in climate.

As for the composition of the evaluating body, the evaluative process can be concentrated or distributed. When concentrated, evaluation is performed by a single

\footnotetext{
${ }^{10}$ This is not always the case; triggers may be monitored by the bureaucracy, the constituency, or a combination of the two. See Chap. 13 for a more complete typology of trigger monitoring mechanisms and supporting organizational constructs.
} 
organization. This may be the organization that develops rules or policy frameworks, or an organization consuming expert knowledge of the system. A distributed evaluative body comprises two or more organizations elaborating permutations of the rulemaking body and/or expert communities. In the case of flood risk management, formal evaluation is traditionally concentrated. In the Netherlands, the Rijkswaterstaat used to rely heavily on its own civil engineers to decide when flood safety rules needed to be adjusted. After the near flooding of the Rhine and Meuse rivers in 1993 and 1995, it was decided to give the rivers more room, as an alternative to further strengthening and heightening the existing dikes. This broadened the knowledge community associated with the flood safety domain. The distributed evaluative bodies brought to the decision broadened the epistemic communities in the flood safety domain. A further broadening followed in 2017, as a new type of flood safety standard developed by the Delta programme came into effect that more systematically follows the risk approach, thereby incorporating population and value of investments into the flood safety equation.

The third aspect of Planned Adaptation focuses on the relationship between the organization that assesses the rules and the parties affected by (changes in) the rules. In the case of flood risk management, a strong coupling can be observed: experts from the Rijkswaterstaat and waterboards are heavily involved in developing, applying, and adapting the rules.

\subsubsection{Rethink Monitoring and Evaluation}

A well-functioning monitoring and evaluation (M\&E) system is the conditio sine qua non for the implementation of an adaptive strategy. Choosing an adaptive approach implies that a system for the timely detection and interpretation of relevant signals has to be installed, and that the decisionmaking process has to be designed to translate these signals directly into suggestions for adjustments of policy frameworks, strategies, and plans at different levels of government.

The goals for monitoring and evaluation, as set by the National Steering Group Delta programme, are:

1. Generate information on changes in external conditions that might require adjustments of policy frameworks, strategies, and plans;

2. Fuel learning processes by facilitating the sharing of successes and the exchange of opportunities for further improvements;

3. Provide a basis for the external justification of the budget and energy spent.

The last goal is standard for all administrative processes and programmes. The following text concentrates on the first two goals.

\section{Generate information on changes in external conditions}

The ambition to adjust plans in a timely manner implies that M\&E is about more than the actions (output) and their effects (outcomes). It is also about developments in the 
surrounding world, about the effects of these developments on the effectiveness and efficiency of the programmed actions and contingent actions, and on the results of ongoing research on the assumptions underlying the plans.

The M\&E system for the Delta programme, named monitoring, analyzing, acting (MAA), distinguishes three groups of developments that may require adjustment of choices and plans: "knowledge and innovation," "climatic and socio-economic developments," and "changes in societal preferences." These developments and their implications for the Delta Decisions, regional strategies, and Delta Plans are monitored by the MAA system. Observed and modeled developments can be analyzed in relation to the tipping points in the adaptation pathways. In a broader sense, only developments that are more extreme than the Delta Scenarios need attention, as the present strategies have been designed to be robust for the whole field of future conditions spanned by the Delta scenarios.

For the timely detection of external developments, the Signal Group Delta programme was set up (Haasnoot et al. 2018). It has been operational since 2017. The Signal Group is comprised of experts from knowledge institutes specialized in the domains of climate, water management, and spatial planning. In its first year, it identified and discussed 20 external developments that might require adjustments of the present strategies. Applying the secondary evaluative rules ${ }^{11}$ described in the previous subsection, two developments were identified that would justify a systematic review of strategies and plans: an acceleration of the deterioration processes of the Antarctic ice cover (possibly leading to an increase of the sea level rise), and an increase in the frequency and intensity of cloudbursts. These developments are now the subject of in-depth research. Research programmes like the Dutch "National Knowledge and Innovation programme Water and Climate" (NKWK) have a major role in generating the needed information. The evaluative character of the secondary rules indicates active monitoring producing knowledge sufficient to inform a change in (primary) rules. Those changes are governed by (secondary) rules of change that, depending on the discretion imbued upon the evaluative body, may imply direct changes in the rules based exclusively on the findings, or be a part of a political process.

Fuel learning processes; link monitoring and evaluation results directly to decisionmaking

MMA is designed to facilitate multi-level programmeming in which the programmeming of measures is jointly done by the different levels of government. It focuses $\mathrm{M} \& \mathrm{E}$ efforts on answering four governance questions:

- Are we "on scheme"? Have the measures that were programmed been executed in time?

\footnotetext{
${ }^{11}$ MMA monitors the adaptive process, not the substance of system integrity. Monitoring and goals related to the adaptive process itself may be informed by progress on monitoring and evaluating the substance, but ultimately the objective is to ensure the integrity of the adaptive elements of the system. At a system level, this is one of the components of the obligation to system integrity.
} 
- Are we "on track"? Do the executed and planned measures suffice to reach the goals of the programme ${ }^{12}$ ?

- Do we follow an integrated approach? Do we reach out to match the design, planning, and location of our interventions with ambitions in other policy domains?

- Do we follow a participative approach? Do we actively involve stakeholders and citizens in our planning process?

To facilitate the adaptation of the policy frameworks, strategies, and plans to new insights, MMA contains two monitoring lines: a blue line and a green line. In the blue line, the elaboration and implementation of the strategies and plans are followed. Monitoring if the measures are executed in time provides the answer to the question if the Delta programme is "on scheme." The blue line is about output. The subprogrammes of the Delta programme have the lead in answering the "on scheme" question.

The green line focuses on a timely detection of external developments that might require adjusting the Delta Decisions, Regional Strategies, or Delta Plans. Here, the specialized knowledge institutes represented in the Signal Group have the lead. The findings of the Signal Group are discussed in the Delta programme Knowledge Network, which includes the subprogrammes of the Delta programme, the responsible authorities, and the most relevant knowledge institutes.

Twice a year, the Signal Group and the Knowledge Network meet to discuss output (blue line) and external developments (green line). These discussions provide input for the answer to the question of whether the Delta programme is "on track" and for distilling statements about outcomes: Are the measures that we are executing, plus the ones that we have planned, still sufficient? Do they continue to fulfill obligations to system integrity, given observed and expected changes in external conditions, based on the goals that were formulated? Or, is it necessary to update the rules governing the adaptive elements of the system and/or the goals that represent the obligation to substantive system integrity?

These statements are then used to formulate advice on the elaboration, implementation, and adjustment of the Delta Decisions, Regional Strategies, and Delta Plans. Depending on their content, the advice targets the appropriate scales of action and government level, distinguishing among the Delta Decisions, the Regional Strategies, and the Delta Plans (see Fig. 14.1).

Figure 14.1 shows that the information coming from the blue line (monitoring the elaboration and implementation of strategies and plans - the three blocks on the left) is discussed in combination with the information from the green line (monitoring external developments - the three blocks at the top). The results of these discussions form the basis for formulating advice for the appropriate level of decisionmaking (the orange blocks on the right), for each of the three abstraction levels (the beams in the middle).

\footnotetext{
${ }^{12}$ Goals considered necessary and enough to safeguard the integrity of the system.
} 


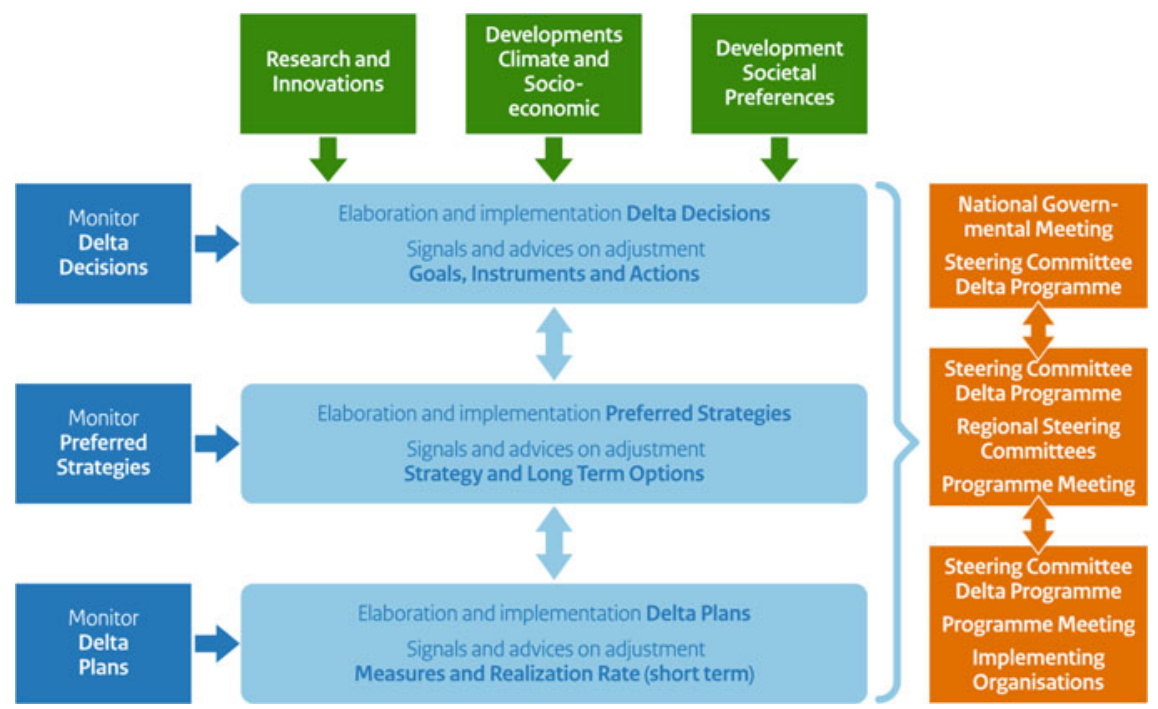

Fig. 14.1 Structure of the monitoring, analyzing, and acting (MAA) system of the Delta programme

\subsection{Conclusions, Reflections, and Outlook}

The preceding sections of this chapter have shown how deep uncertainty was dealt with in practice, in setting up and running a large-scale climate adaptation programme. Is enough being done and planned to prevent a next flood from happening? Do new insights require further stepping up the efforts? Or is the Netherlands already overinvesting - preparing for climate conditions that will never materialize? Only time can tell for sure. But reflecting on what was done in order to deal with deep uncertainty in the different phases, the following observations are considered worth sharing.

\section{Phase I (prior to the start of the programme): politicization and depoliticization}

The ambition to mobilize political interest in starting up an ambitious programme for dealing with an issue characterized by deep uncertainty, and to subsequently position politics at arm's length in the phase of actual programmeming of measures, has been realized to a certain degree. The Parliament and Senate agreed that the water-related challenges of climate proofing the Netherlands have to be addressed in a long-term programme, secured by the underlying Delta Act, the position of a relatively independent Delta programme Commissioner assigned the task to manage the programme, and a guaranteed budget of $€ 1$ billion per year for twenty years.

Already in its first years, this robust structure has proven its added value. Attempts to dismantle the structure by a short-lived government in which one of the partners was not motivated to address climate change failed because of the programme's legislative foundation. The subsequent government, composed of parties that all rec- 
ognized the urgency of dealing with climate change, actively contributed to keeping the process of setting up the Delta programme moving forward.

In the process of planning the actual implementation of concrete measures, like the heightening and strengthening of dikes and the creation of bypasses in the river system, politics did interfere. In specific situations, local stakeholders managed to mobilize local or national political commitments to significantly adjust or completely obstruct flood safety projects. Interventions of the Delta programme Commissioner, proposing alternative, less invasive, flood protection measures, were necessary to prevent stalemate situations from emerging. ${ }^{13}$

Phase II (developing strategies and decisionmaking): explicitly incorporating uncertainty into strategy development

The regular evaluations contributed to improvements over time and helped secure commitment to the working method that had evolved. Practice showed that the ADM approach for incorporating uncertainty into strategy development is relatively easy to explain to laymen and decisionmakers, and offers enough room for tailoring. The online survey on the use of ADM that addressed the people that actually worked on the formulation of the Delta Decisions and Regional Strategies helped to further improve the approach and tailor assistance to the regional subprogrammes of the Delta programme, where the strategy development was taking place. The results of the study on the challenges for the further development of the Adaptation Pathways Approach is being translated into a "research—design—use agenda."

The process of designing and discussing adaptation pathways has proven to be effective in keeping decision processes moving forward to final approval of the long-term plan. By making transparent how short-term decisions can be related to long-term tasks, it has motivated and facilitated policymakers, politicians, and other decisionmakers to incorporate uncertainty about future conditions into their decisions and plans, and to keep long-term, contingent actions open. It has helped to raise awareness about uncertainties, offered visualization of multiple alternatives, provided political support for taking the measures necessary for securing the possibility to implement contingent actions at a later stage, and motivated decisionmakers to modify their plans to better accommodate future conditions.

On a more general level, it can be concluded that DMDU approaches, such as described in the scientific literature, can profit from feedback-feedback from other researchers, and feedback from practitioners. Organizing the latter might be more time-consuming, but is likely to be very effective.

\footnotetext{
${ }^{13}$ This could also be framed as feedback that facilitated solutions that were amenable to all stakeholders, including those affected by local elements of the system being implemented or modified. Even if the political process could be seen as adversarial, it can also be viewed as constructive if framed correctly. This may be a lesson in the early feedback necessary for Phase I planning to avoid conflicts down the line.
} 
Phase III (elaboration, implementation, and adjusting strategies): rethinking monitoring and evaluation

The notion of combining clock-driven triggers for adaptation with stochastic triggers has helped in structuring monitoring efforts. Rethinking monitoring and evaluation in the context of deep uncertainties and adaptive approaches have resulted in tailoring a monitoring and evaluation system for the Delta programme. That system, labelled "Monitor, Analyze, Act" (MAA) has been applied for 2 years. Lessons learned from these first years are:

- An M\&E structure that focuses attention on a small number of central administrative questions helps to keep policymakers and researchers actively involved, and to keep national and regional steering groups interested in the output of the system;

- The processes of collecting information and discussing results unveil discrepancies among different organizations in views on the distribution of responsibilities;

- The way the MAA system is set up stimulates technical and strategic learning. Yearly and 6-yearly reviews directly follow from the processes of gathering information and discussing results.

- Outlook. It is concluded that there is still a lot of work to be done:

- The relevance of the output from the MAA system for steering at the regional level needs to be improved. This is crucial because the regional subprogrammes are the major source of information on the implementation process.

- The original planning of the implementation of the MAA system was too optimistic. Parts are still under construction. It has become clear that criteria for determining if the measures that are executed and planned suffice to reach the goals of the Delta programme in time (outcomes) need more reflection, research, and discussion. Also the goals of the strategies still need to be elaborated in more detail and made more concrete in order to be able to measure their outcomes.

- The relation between the criteria that can be measured and the criteria that can be modeled needs additional reflection and discussion.

\section{References}

Bloemen, P., Reeder, T., Zevenbergen, C., Rijke, J., \& Kingsborough, A. (2017). Lessons learned from applying adaptation pathways in flood risk management and challenges for the further development of this approach. Mitigation and Adaptation Strategies for Global Change. https:// doi.org/10.1007/s11027-017-9773-9.

Bruggeman, W. A., \& Dammers, E. (Eds.). (2013). Deltascenario's voor 2050 en 2100, nadere uitwerking 2012-2013. The Hague, The Netherlands: Ministry of Infrastructure and Environment.

Bruggeman, W., Hommes, S., Haasnoot, M., Te Linde, A., \& van der Brugge, R. (2011). Deltascenarios: Scenarios for robustness analysis of strategies for fresh water supply and water safety (Deltascenario's: Scenario's voor robuustheidanalyse van maatregelen voor zoetwatervoorziening en waterveiligheid). Technical Report, Deltares (in Dutch).

Council for Housing, Spatial Planning, and Environment (VROM-raad). (2007). De hype voorbij - Klimaatverandering als structureel ruimtelijk vraagstuk (in Dutch). 
de Haan, F. J., Ferguson, B. C., Adamowicz, R. C., Johnstone, P., Brown, R. R., \& Wong, T. H. F. (2014). The needs of society: A new understanding of transitions, sustainability and liveability. Technological Forecasting and Social Change, 85. http://dx.doi.org/10.1016/j.techfore.2013.09. 005.

De Ingenieur - interview Spaargaren. (oktober 2016). De Oosterschelde bracht het keerpunt (in Dutch).

Delta Committee. (1960). Final report of the Delta Committee (Rapport Deltacommissie. Eindverslag en interim adviezen). Technical Report (in Dutch).

Delta Programme Commissioner. (2011). The 2012 Delta Programme Working on the delta. Acting today, preparing for tomorrow (English version). Ministry of Transport Public Works and Water Management, Ministry of Agriculture Nature and Food Quality, Ministry of Housing Spatial Planning and the Environment, Dutch national government.

Delta Programme Commissioner. (2013). The 2014 Delta Programme Working on the delta. Promising solutions for tasking and ambitions (English version). Ministry of Transport Public Works and Water Management, Ministry of Agriculture Nature and Food Quality, Ministry of Housing Spatial Planning and the Environment, Dutch national government.

Delta Programme Commissioner. (2014). The 2015 Delta Programme Working on the Delta. The decisions to keep the Netherlands safe and liveable (English version). Ministry of Infrastructure and the Environment, Ministry of Economic Affairs, Dutch national government.

Delta Programme Commissioner. (2017). The 2018 Delta Programme Working on the Delta. Continuing the work on sustainable and safe delta (English version). Ministry of Infrastructure and the Environment, Ministry of Economic Affairs, Dutch national government.

Dessai, S., \& van der Sluijs, J. P. (2007). Uncertainty and climate change adaptation: A scoping study. Copernicus Institute for Sustainable Development and Innovation, Department of Science Technology and Society.

Diermanse, F. L. M., Kwadijk, J. C. J., Beckers, J. V. L., \& Crebas, J. I. (2010). Statistical trend analysis of annual maximum discharges of the Rhine and Meuse rivers. In British Hydrological Society Third International Symposium, Newcastle 2010.

Environment Agency United Kingdom. (2012). Managing flood risk through London and the Thames Estuary TE2100 Plan. London: Environment Agency.

Folke, C., Carpenter, S. R., Walker, B., Scheffer, M., Chapin, T., \& Rockstrom, J. (2010). Resilience thinking: Integrating resilience, adaptability and transformability. Ecology and Society, 15(4), 20. http://www.ecologyandsociety.org/vol15/iss4/art20/.

Funfgeld, H., Lonsdale, K., \& Bosomworth, K. (2018). Beyond the tools: Supporting adaptation when organisational resources and capacities are in short supply. Climatic Change. https://doi. org/10.1007/s10584-018-2238-7.

Haasnoot, M., Schasfoort, F., Eilander, D., Diermanse, F., \& Oosterberg, W. (2017). Knikpunten in zicht: een signaleringssysteem voor tijdige adaptatie in het Deltaprogramma Zoetwater; 11200588-003 @ Deltares, 2017, B.

Haasnoot, M., Schellekens, J., Beersma, J. J., Middelkoop, H., \& Kwadijk, J. C. J. (2015). Transient scenarios for robust climate change adaptation illustrated for water management in the Netherlands. Environmental Research Letters. https://doi.org/10.1088/1748-9326/10/10/105008.

Haasnoot, M., Van 't Klooster, S., \& van Alphen, J. (2018). Designing a monitoring system to detect signals to uncertain climate change. Global Environmental Change, 52, 273-285. https://doi.org/ 10.1016/j.gloenvcha.2018.08.003.

Hall, J., Arheimer, B., Borga, M., Brazdil, R., Claps, P., et al. (2014). Understanding flood regime changes in Europe: A state of the art assessment. Hydrology and Earth System Sciences, European Geosciences Union, 18(7), 2735-2772. https://doi.org/10.5194/hess-18-2735-2014\%3e\%3chal01141526.

Hart, H. (1994). The concept of law (2nd ed.). Oxford: Oxford University Press.

Huntjens, P., Pahl-Wostl, C., Rihoux, B., Schlüter, M., Flachner, Z., Neto, S., et al. (2011). Adaptive water management and policy learning in a changing climate: A formal comparative analysis of 
eight water management regimes in Europe, Africa and Asia. Environmental Policy and Governance, $21,145-163$.

International Monetary Fund (IMF). (2018). World Economic Outlook Data Base.

Klijn, F., de Bruijn, K. M., Knoop, J., \& Kwadijk, J. C. J. (2012). Assessment of the Netherlands' flood risk management policy under global change. Ambio, 41, 180-192. https://doi.org/10.1007/ s13280-011-0193-x.

KNMI. (2014). KNMI '14 climate scenarios for the Netherlands; A guide for professionals in climate adaptation. De Bilt, The Netherlands: KNMI.

Kwakkel, J., \& Haasnoot, M. (this book, Chapter 15). Supporting decisionmaking under deep uncertainty: A taxonomy of approaches and tools.

Lawrence, J., Haasnoot, M., McKim, L., Atapattu, D., Campbell, G., \& Stroombergen, A. (this book, Chapter 9). Dynamic Adaptive Policy Pathways: From Theory to Practice.

Lonsdale, K., Pringle, P., \& Turner, B. (2015). Transformative adaptation: What it is, why it matters and what is needed. UK Climate Impacts Programme, University of Oxford, Oxford, UK.

McCray, L. E., Oye, K. A., \& Petersen, A. C. (2010). Planned adaptation in risk regulation: An initial survey of US environmental, health, and safety regulation. Technological Forecasting and Social Change, 77(6), 951-959. https://doi.org/10.1016/j.techfore.2009.12.001.

Ministries of Housing, Spatial Planning, and Environment, of Economic Affairs, of Agriculture Nature and Fishery, and of Transport, Public Works and Water Management. (2006). Werkplan Nationaal Programma Adaptatie Ruimte en Klimaat (ARK).

Ministries of Housing, Spatial Planning, and Environment, of Economic Affairs, of Agriculture Nature and Fishery, and of Transport, Public Works and Water Management. (2007). The National Adaptation Strategy.

Ministry of Transport, Public Works and Water Management. (2007). The Water Vision (Watervisie. Nederland veroveren op de toekomst).

Ministry of Transport, Public Works and Water Management. (2008). The National Water Plan.

Netherlands Environment Assessment Agency (Milieu- en Natuurplanbureau). (2005). The effects of climate change in the Netherlands.

Netherlands Environment Assessment Agency (Milieu- en Natuurplanbureau) and The National Institute for Public Health and the Environment (RIVM). (2004). Risico's in bedijkte termen een thematische evaluatie van het Nederlandse veiligheidsbeleid tegen overstromen.

Netherlands Scientific Council for Government Policy (WRR). (2006). Klimaatstrategie - tussen ambitie en realisme.

OECD. (2014). Water governance in the Netherlands, fit for the future? OECD studies on Water. Paris: OECD Publishing.

Office for the Senior Civil Service (ABD), Ministry of the Interior and Kingdom Relations. (2016). Statutory ex-post evaluation of the Delta Act.

Petersen, A. C., \& Bloemen, P. (2015). Planned adaptation in design and testing of critical infrastructure: The case of flood safety in The Netherlands (Proceedings paper). In International Symposium for Next Generation Infrastructure Conference Proceedings. Retrieved 2016-02-07, http://www. ucl.ac.uk/steapp/isngi/proceedings.

Rijke, J. (2014). Adaptief deltamanagement - Ontstaansgeschiedenis en toepassing in het Deltaprogramma (in Dutch).

Rijke, J., Farrely, M., Brown, R., \& Zevenbergen, C. (2013). Configuring transformative governance to enhance resilient urban water systems. Environmental Science \& Policy, 25, 62-72. https://doi. org/10.1016/j.envsci.2012.09.012.

Second Delta Committee. (2008). Working together with water: A living land builds for its future. Findings of the Dutch Delta Committee. Ministerie van Verkeer en Waterstaat, The Hague, The Netherlands. Available from http://www.deltacommissie.com/en/advies.

van Alphen, J. (2016). The Delta Programme and updated flood risk management policies in The Netherlands. Journal of Flood Risk Management, 9, 310-319. 
van Buuren, A., Driessen, P. J., van Rijswick, M., Rietveld, P., Salet, W., Spit, T., \& Teisman, G. (2013). Towards adaptive spatial planning for climate change: Balancing between robustness and flexibility. Journal for European Environmental and Planning Law, 10(1), 29-53.

van Buuren, A., \& Teisman, G. (2014). Samen verder werken aan de delta. De governance van het Nationaal Deltaprogramma na 2014 (in Dutch).

van Rhee, G. (2012). Handreiking Adaptief Deltamanagement - definitief concept. Stratelligence, Leiden (in Dutch).

van Twist, M., Schulz, M., van der Steen, M., \& Ferket, J. (2013). De Deltacommissaris. Een kroniek van de instelling van een regeringscommissaris voor de Nederlandse delta. NSOB. ISBN 97890-75297-33-I.

Zevenbergen, C., Rijke, J., Herk, S., \& Bloemen, P. (2015). Room for the river: A stepping stone in adaptive delta management. International Journal of Water Governance, 3, 121-114. https:// doi.org/10.7564/14-ijwg63.

Drs. Pieter J. T. M. Bloemen (Ministry of Infrastructure and Water Management-Staff Delta Programme Commissioner) is the Chief Strategic Officer of the Dutch Delta programme. He is responsible for the development and application of Adaptive Delta Management. He led the Strategic Environmental Assessment of the Delta Decisions and preferred regional strategies published in 2014. He presently works on the development of a monitoring and evaluation system that matches the adaptive approach of the Delta programme and is responsible for the first sixyearly review of the Delta Decisions and preferred regional strategies, planned for 2020. Bloemen has been Visiting Researcher at IHE Delft Institute of Water Education (Chair Group Flood Resilience) since January 2015 and is working on a Ph.D. thesis on the governance of the adaptive approach.

Floris Hammer, M.Sc. (formerly of Ministry of Infrastructure and Water Management-Staff Delta Programme Commissioner) worked on the initial development of ADM. He researched and described several possible applications of ADM in the Delta programme. Examples are an adaptive planning of shipping infrastructure and water quality/safety measures around the Volkerak Zoommeer region. He trained policy advisors and civil servants in applying ADM in practice. Floris is currently an independent consultant, specializing in executing technical programmes and projects in complex political environments.

Dr. ir. Maarten J. van der Vlist (Ministry of Infrastructure and Water Management, Rijkswaterstaat) is currently principle expert on adaptive water management at the Rijkswaterstaat and has a joint appointment as Associate Professor adaptive water management and land use planning at Wageningen University. He has a Ph.D. in agricultural engineering on the issue of sustainability as a task of planning. His recent work has focused on replacement and renovations (redesigning) of aging water resource infrastructure in the national waterways and national water system in the Netherlands. He was co-founder of Next Generation Infrastructures 2.0, a collaboration among the most important infrastructure managers in the Netherlands, supported by a scientific research programme. He is one of the key players of De Bouwcampus, a center for co-creation between experts on issues such as energy transition, and replacement and renovation. In his research at Wageningen University, he focusses on the impact of climate change and the related uncertainty on renewal of aging infrastructure and the design of alternatives on the system level and the object level.

Pieter Grinwis was closely involved in the establishment of the Delta Programme as a political assistant to the State Secretary for Transport, Public Works, and Water Management (2007-2010). From 2010 to 2015, he worked at the Delta programme Commissioner as a political and financial-economic advisor for the Delta Commissioner on the initial development of ADM. He was 
particularly concerned with valuing flexibility in investment decisions and with the level of the discount rate in relation to dealing with long-term effects. Pieter is currently a Member of the Municipal Council of The Hague and a Policy Officer for the ChristenUnie in the Dutch Senate and the House of Representatives.

Drs. Jos van Alphen (Ministry of Infrastructure and Water Management-Staff Delta Programme Commissioner) is senior advisor of the Dutch Delta Programme. During his former positions at the Rijkswaterstaat, he became an international expert on flood risk management. Presently, he is responsible for knowledge management in the Delta Programme and is Chairman of the Delta Programme Signal Group. The Signal Group monitors external developments that might influence the implementation of the adaptive strategies. From his experience with the Dutch Delta Programme, van Alphen supports the preparation and implementation of delta plans in Bangladesh and Manila Bay.

Open Access This chapter is licensed under the terms of the Creative Commons Attribution 4.0 International License (http://creativecommons.org/licenses/by/4.0/), which permits use, sharing, adaptation, distribution and reproduction in any medium or format, as long as you give appropriate credit to the original author(s) and the source, provide a link to the Creative Commons licence and indicate if changes were made.

The images or other third party material in this chapter are included in the chapter's Creative Commons licence, unless indicated otherwise in a credit line to the material. If material is not included in the chapter's Creative Commons licence and your intended use is not permitted by statutory regulation or exceeds the permitted use, you will need to obtain permission directly from the copyright holder. 